\title{
Corporate Accounting Fraud: A Case Study of Satyam Computers Limited
}

\author{
Madan Lal Bhasin \\ Bang College of Business, KIMEP University, Almaty, Republic of Kazakhstan \\ Email: madan.bhasin@rediffmail.com
}

Received January 15, 2013; revised March 12, 2013; accepted March 28, 2013

Copyright (C) 2013 Madan Lal Bhasin. This is an open access article distributed under the Creative Commons Attribution License, which permits unrestricted use, distribution, and reproduction in any medium, provided the original work is properly cited.

\begin{abstract}
From Enron, WorldCom and Satyam, it appears that corporate accounting fraud is a major problem that is increasing both in its frequency and severity. Research evidence has shown that growing number of frauds have undermined the integrity of financial reports, contributed to substantial economic losses, and eroded investors' confidence regarding the usefulness and reliability of financial statements. The increasing rate of white-collar crimes demands stiff penalties, exemplary punishments, and effective enforcement of law with the right spirit. An attempt is made to examine and analyze in-depth the Satyam Computer's "creative-accounting" scandal, which brought to limelight the importance of "ethics and corporate governance" (CG). The fraud committed by the founders of Satyam in 2009, is a testament to the fact that "the science of conduct is swayed in large by human greed, ambition, and hunger for power, money, fame and glory”. Unlike Enron, which sank due to "agency” problem, Satyam was brought to its knee due to 'tunneling' effect. The Satyam scandal highlights the importance of securities laws and CG in 'emerging' markets. Indeed, Satyam fraud "spurred the government of India to tighten the CG norms to prevent recurrence of similar frauds in future". Thus, major financial reporting frauds need to be studied for "lessons-learned" and "strategies-to-follow" to reduce the incidents of such frauds in the future.
\end{abstract}

Keywords: Corporate Accounting Frauds; Satyam Computers; Case Study; India; Corporate Governance; Accounting and Auditing Standards

\section{Introduction}

\subsection{What Is Fraud?}

Fraud is a worldwide phenomenon that affects all continents and all sectors of the economy. Fraud encompasses a wide-range of illicit practices and illegal acts involving intentional deception, or misrepresentation. According to the Association of Certified Fraud Examiners (ACFE), fraud is "a deception or misrepresentation that an individual or entity makes knowing that misrepresentation could result in some unauthorized benefit to the individual or to the entity or some other party" [1]. In other words, mistakes are not fraud. Indeed, in fraud, groups of unscrupulous individuals manipulate, or influence the activities of a target business with the intention of making money, or obtaining goods through illegal or unfair means. Fraud cheats the target organization of its legitimate income and results in a loss of goods, money, and even goodwill and reputation. Fraud often employs illegal and immoral, or unfair means. It is essential that or- ganizations build processes, procedures and controls that do not needlessly put employees in a position to commit fraud and that effectively detect fraudulent activity if it occurs. The fraud involving persons from the leadership level is known under the name "managerial fraud" and the one involving only entity's employees is named "fraud by employees' association".

\subsection{Magnitude of Fraud Losses: A Glimpse}

Organizations of all types and sizes are subject to fraud. On a number of occasions over the past few decades, major public companies have experienced financial reporting fraud, resulting in turmoil in the capital markets, a loss of shareholder value, and, in some cases, the bankruptcy of the company itself. Although, it is generally accepted that the Sarbanes-Oxley Act has improved corporate governance and decreased the incidence of fraud, recent studies and surveys indicate that investors and management continue to have concerns about financial statement fraud. For example: 
- The ACFE's “2010 Report to the Nations on Occupational Fraud and Abuse" [1] found that financial statement fraud, while representing less than five percent of the cases of fraud in its report, was by far the most costly, with a median loss of $\$ 1.7$ million per incident. Survey participants estimated that the typical organization loses $5 \%$ of its revenues to fraud each year. Applied to the 2011 Gross World Product, this figure translates to a potential projected annual fraud loss of more than $\$ 3.5$ trillion. The median loss caused by the occupational fraud cases in our study was $\$ 140,000$. More than one-fifth of these cases caused losses of at least $\$ 1$ million. The frauds reported to us lasted a median of 18 months before being detected.

- “Fraudulent Financial Reporting: 1998-2007”, from the Committee of Sponsoring Organizations of the Treadway Commission (the 2010 COSO Fraud Report) [2], analyzed 347 frauds investigated by the US Securities and Exchange Commission (SEC) from 1998 to 2007 and found that the median dollar amount of each instance of fraud had increased three times from the level in a similar 1999 study, from a median of \$4.1 million in the 1999 study to \$12 million. In addition, the median size of the company involved in fraudulent financial reporting increased approximately six-fold, from $\$ 16$ million to $\$ 93$ million in total assets and from $\$ 13$ million to $\$ 72$ million in revenues.

- A “2009 KPMG Survey” [3] of 204 executives of US companies with annual revenues of $\$ 250$ million or more found that 65 percent of the respondents considered fraud to be a significant risk to their organizations in the next year, and more than one-third of those identified financial reporting fraud as one of the highest risks.

- Fifty-six percent of the approximately 2100 business professionals surveyed during a "Deloitte Forensic Center" [4] webcast about reducing fraud risk predicted that more financial statement fraud would be uncovered in 2010 and 2011 as compared to the previous three years. Almost half of those surveyed (46 percent) pointed to the recession as the reason for this increase.

- According to “Annual Fraud Indicator 2012” conducted by the National Fraud Authority (UK) [5], "The scale of fraud losses in 2012, against all victims in the UK, is in the region of $£ 73$ billion per annum. In 2006, 2010 and 2011, it was $£ 13, £ 30$ and $£ 38$ billions, respectively. The 2012 estimate is significantly greater than the previous figures because it includes new and improved estimates in a number of areas, in particular against the private sector. Fraud harms all areas of the UK economy”.
Moreover, financial statement fraud was a contributing factor to the recent financial crisis and it threatened the efficiency, liquidity and safety of both debt and capital markets [6]. Furthermore, it has significantly increased uncertainty and volatility in financial markets, shaking investor confidence worldwide. It also reduces the creditability of financial information that investors use in investment decisions. When taking into account the loss of investor confidence, as well as, reputational damage and potential fines and criminal actions, it is clear why financial misstatements should be every manager's worst fraud-related nightmare [7].

\subsection{Who Commits Frauds?}

Everyday, there are revelations of organizations behaving in discreditable ways [8]. Generally, there are three groups of business people who commit financial statement frauds. They range from senior management (CEO and CFO); mid- and lower-level management and organizational criminals [9]. CEOs and CFOs commit accounting frauds to conceal true business performance, to preserve personal status and control and to maintain personal income and wealth. Mid- and lower-level employyees falsify financial statements related to their area of responsibility (subsidiary, division or other unit) to conceal poor performance and/or to earn performance-based bonuses. Organizational criminals falsify financial statements to obtain loans, or to inflate a stock they plan to sell in a "pump-and-dump" scheme. While many changes in financial audit processes have stemmed from financial fraud, or manipulations, history and related research repeatedly demonstrates that a financial audit simply cannot be relied upon to detect fraud at any significant level.

\subsection{Consequences of Fraudulent Reporting}

Fraudulent financial reporting can have significant consequences for the organization and its stakeholders, as well as for public confidence in the capital markets. Periodic high-profile cases of fraudulent financial reporting also raise concerns about the credibility of the US financial reporting process and call into question the roles of management, auditors, regulators, and analysts, among others. Moreover, corporate fraud impacts organizations in several areas: financial, operational and psychological [10]. While the monetary loss owing to fraud is significant, the full impact of fraud on an organization can be staggering. In fact, the losses to reputation, goodwill, and customer relations can be devastating. When fraudulent financial reporting occurs, serious consequences ensue. The damage that result is also widespread, with a sometimes devastating "ripple" effect [6]. Those affected may range from the "immediate" victims (the company's 
stockholders and creditors) to the more "remote" (those harmed when investor confidence in the stock market is shaken). Between these two extremes, many others may be affected: "employees" who suffer job loss or diminished pension fund value; "depositors" in financial institutions; the company's "underwriters, auditors, attorneys, and insurers"; and even honest "competitors" whose reputations suffer by association.

As fraud can be perpetrated by any employee within an organization or by those from the outside, therefore, it is important to have an effective "fraud management" program in place to safeguard your organization's assets and reputation. Thus, prevention and earlier detection of fraudulent financial reporting must start with the entity that prepares financial reports. Given the current state of the economy and recent corporate scandals, fraud is still a top concern for corporate executives. In fact, the sweeping regulations of Sarbanes-Oxley, designed to help prevent and detect corporate fraud, have exposed fraudulent practices that previously may have gone undetected. Additionally, more corporate executives are paying fines and serving prison time than ever before. No industry is immune to fraudulent situations and the negative publicity that swirls around them. The implications for management are clear: every organization is vulnerable to fraud, and managers must know how to detect it, or at least, when to suspect it.

\section{Review of Literature}

Starting in the late 1990s, a wave of corporate frauds in the United States occurred with Enron's failure perhaps being the emblematic example. Jeffords [11] examined 910 cases of frauds submitted to the "Internal Auditor" during the nine-year period from 1981 to 1989 to assess the specific risk factors cited in the Treadway Commission Report. He concluded that "approximately 63 percent of the 910 fraud cases are classified under the internal control risks". In addition, Smith [12] offered a "typology" of individuals who embezzle. He indicated that embezzlers are "opportunist's type", who quickly detects the lack of weakness in internal control and seizes the opportunity to use the deficiency to his benefit. Similarly, Ziegenfuss [13] performed a study to determine the amount and type of fraud occurring in "state and local" governments. His study revealed that the most frequently occurring types of fraud are misappropriation of assets, theft, false representation; and false invoice.

On the other hand, Haugen and Selin [14] in their study discussed the value of "internal" controls, which depends largely on management's integrity and the ready availability of computer technology, which assisted in the commitment of crime. Sharma and Brahma [15] emphasized on "bankers" responsibility on frauds; bank frauds could crop-up in all spheres of bank's dealing. Major cause for perpetration of fraud is laxity in observance in laid-down system and procedures by supervising staff. Harris and William [16], however, examined the reasons for "loan" frauds in banks and emphasized on due diligence program. Beirstaker, Brody, Pacini [17] in their study proposed numerous fraud protection and detection techniques. Moreover, Willison [18] examined the causes that led to the breakdown of "Barring" Bank. The collapse resulted due to the failures in management, financial and operational controls of Baring Banks.

Choo and Tan [19] explained corporate fraud by relating the "fraud-triangle" to the "broken trust theory" and to an "American Dream" theory, which originates from the sociological literature, while Schrand and Zechman [20] relate executive over-confidence to the commitment of fraud. Moreover, Bhasin [21] examined the reasons for "check" frauds, the magnitude of frauds in Indian banks, and the manner, in which the expertise of internal auditors can be integrated, in order to detect and prevent frauds in banks by taking "proactive" steps to combat frauds. Chen [22] in his study examined "unethical" leadership in the companies and compares the role of unethical leaders in a variety of scenarios. Through the use of computer simulation models, he shows how a combination of CEO's narcissism, financial incentive, shareholders' expectations and subordinate silence as well as CEO's dishonesty can do much to explain some of the findings highlighted in recent high-profile financial accounting scandals. According to a research study performed by Cecchini et al. [23], the authors provided a methodology for detecting "management" fraud using basic financial data based on "support vector machines".

From the above, it is evident that majority of studies were performed in developed, Western countries. However, the manager's behavior in fraud commitment has been relatively unexplored so far. Accordingly, the objective of this paper is to examine managers' unethical behaviors in Satyam Computer Limited, which constitute an ex-post evaluation of alleged or acknowledged fraud case. Unfortunately, no study has been conducted to examine behavioral aspects of manager's in the perpetuation of corporate frauds in the context of a developing economy, like India. Hence, the present study seeks to fill this gap and contributes to the literature.

\section{Research Methodology, Objectives and Sources of Information}

Financial reporting practice can be developed by reference to a particular setting in which it is embedded. Therefore, "qualitative" research could be seen useful to explore and describe fraudulent financial reporting practice. Here, two issues are crucial. First, to understand why 
and how a "specific" company is committed to fraudulent financial reporting practice an appropriate "interpretive" research approach is needed. Second, case study conducted as part of this study, looked specifically at the largest fraud case in India, involving Satyam Computer Services (Satyam). Labelled as “India's Enron” by the Indian media, the Satyam accounting fraud has comprehensively exposed the failure of the regulatory oversight mechanism in India. No doubt, to design better accounting systems, we need to understand how accounting systems operate in their social, political and economic contexts. The main objectives of this study are to: 1) highlight the Satyam Computers Limited's accounting scandal by portraying the sequence of events, the aftermath of events, the key parties involved, and major follow-up actions undertaken in India; and 2) what lesions can be learned from Satyam scam?

To complement prior literature, we examined documented behaviors in cases of Satyam corporate scandal, using the evidence taken from press articles, and also applied a "content" analysis to them. In terms of information collection "methodology", we searched for evidence from the press coverage contained in the "Factiva" database. Thus, present study is primarily based on "secondary" sources of data (EBSCO host database) gathered from the related literature published in the journals, newspaper, books, statements, reports. However, as stated earlier, the nature of study is "primarily qualitative, descriptive and analytical”.

\section{Corporate Accounting Scandal at Satyam Computer Services Limited: A Case Study of India's Enron}

Ironically, Satyam means "truth" in the ancient Indian language "Sanskrit" [24]. Satyam won the "Golden Peacock Award" for the best governed company in 2007 and in 2009. From being India's IT “crown jewel” and the country's "fourth largest” company with high-profile customers, the outsourcing firm Satyam Computers has become embroiled in the nation's biggest corporate scam in living memory [25]. Mr. Ramalinga Raju (Chairman and Founder of Satyam; henceforth called "Raju"), who has been arrested and has confessed to a $\$ 1.47$ billion (or Rs. 7800 crore) fraud, admitted that he had made up profits for years. According to reports, Raju and his brother, B. Rama Raju, who was the Managing Director, "hid the deception from the company's board, senior managers, and auditors". The case of Satyam's accounting fraud has been dubbed as “India's Enron”. In order to evaluate and understand the severity of Satyam's fraud, it is important to understand factors that contributed to the "unethical" decisions made by the company's executives. First, it is necessary to detail the rise of Satyam as a competitor within the global IT services market-place. Second, it is helpful to evaluate the driving-forces behind Satyam's decisions: Ramalinga Raju. Finally, attempt to learn some "lessons" from Satyam fraud for the future.

\subsection{Emergence of Satyam Computer Services Limited}

Satyam Computer Services Limited was a "rising-star” in the Indian “outsourced” IT-services industry. The company was formed in 1987 in Hyderabad (India) by Mr. Ramalinga Raju. The firm began with 20 employees and grew rapidly as a "global" business. It offered IT and business process outsourcing services spanning various sectors. Satyam was as an example of “India's growing success”. Satyam won numerous awards for innovation, governance, and corporate accountability. "In 2007, Ernst \& Young awarded Mr. Raju with the 'Entrepreneur of the Year' award. On April 14, 2008, Satyam won awards from MZ Consult's for being a 'leader in India in CG and accountability'. In September 2008, the World Council for Corporate Governance awarded Satyam with the 'Global Peacock Award' for global excellence in corporate accountability” [26]. Unfortunately, less than five months after winning the Global Peacock Award, Satyam became the centerpiece of a "massive" accounting fraud.

By 2003, Satyam's IT services businesses included 13,120 technical associates servicing over 300 customers worldwide. At that time, the world-wide IT services market was estimated at nearly $\$ 400$ billion, with an estimated annual compound growth rate of $6.4 \%$. "The markets major drivers at that point in time were the increased importance of IT services to businesses worldwide; the impact of the Internet on eBusiness; the emergence of a high-quality IT services industry in India and their methodologies; and, the growing need of IT services providers who could provide a range of services". To effectively compete, both against domestic and global competitors, the company embarked on a variety of multi-pronged business growth strategies.

From 2003-2008, in nearly all financial metrics of interest to investors, the company grew measurably. Satyam generated USD $\$ 467$ million in total sales. By March 2008, the company had grown to USD \$2.1 billion. The company demonstrated "an annual compound growth rate of $35 \%$ over that period". Operating profits averaged 21\%. Earnings per share similarly grew, from $\$ 0.12$ to $\$ 0.62$, at a compound annual growth rate of $40 \%$. Over the same period (2003-2009), the company was trading at an average trailing EBITDA multiple of 15.36. Finally, beginning in January 2003, at a share price of 138.08 INR, Satyam's stock would peak at 526.25 INR - a 300\% improvement in share price after nearly five years. Satyam clearly generated significant corporate 
growth and shareholder value. The company was a leading star-and a recognizable name-in a global IT marketplace. The external environment in which Satyam operated was indeed beneficial to the company's growth. But, the numbers did not represent the full picture. The case of Satyam accounting fraud has been dubbed as “India’s Enron”.

\subsection{Mr. Ramalinga Raju and the Satyam Scandal}

On January 7, 2009, Mr. Raju disclosed in a letter (see Annexure) to Satyam Computers Limited Board of Directors that "he had been manipulating the company's accounting numbers for years”. Mr. Raju claimed that he overstated assets on Satyam's balance sheet by $\$ 1.47$ billion. Nearly $\$ 1.04$ billion in bank loans and cash that the company claimed to own was non-existent. Satyam also underreported liabilities on its balance sheet. Satyam overstated income nearly every quarter over the course of several years in order to meet analyst expectations. For example, the results announced on October 17, 2009 overstated quarterly revenues by 75 percent and profits by 97 percent. Mr. Raju and the company's global head of internal audit used a number of different techniques to perpetrate the fraud. "Using his personal computer, Mr. Raju created numerous bank statements to advance the fraud. Mr. Raju falsified the bank accounts to inflate the balance sheet with balances that did not exist. He inflated the income statement by claiming interest income from the fake bank accounts. Mr. Raju also revealed that he created 6000 fake salary accounts over the past few years and appropriated the money after the company deposited it. The company's global head of internal audit created fake customer identities and generated fake invoices against their names to inflate revenue. The global head of internal audit also forged board resolutions and illegally obtained loans for the company" [27]. It also appeared that the cash that the company raised through American Depository Receipts in the United States never made it to the balance sheets.

Greed for money, power, competition, success and prestige compelled Mr. Raju to "ride the tiger”, which led to violation of all duties imposed on them as fiduciaries - the duty of care, the duty of negligence, the duty of loyalty, the duty of disclosure towards the stakeholders. "The Satyam scandal is a classic case of negligence of fiduciary duties, total collapse of ethical standards, and a lack of corporate social responsibility. It is human greed and desire that led to fraud. This type of behavior can be traced to: greed overshadowing the responsibility to meet fiduciary duties; fierce competition and the need to impress stakeholders especially investors, analysts, shareholders, and the stock market; low ethical and moral standards by top management; and, greater emphasis on short-term performance” [28]. According to CBI, the Indian crime investigation agency, the fraud activity dates back from April 1999, when the company embarked on a road to double-digit annual growth. As of December 2008, Satyam had a total market capitalization of $\$ 3.2$ billion dollars.

Satyam planned to acquire a $51 \%$ stake in Maytas Infrastructure Limited, a leading infrastructure development, construction and project management company, for \$300 million. Here, the Rajus’s had a 37\% stake. The total turnover was $\$ 350$ million and a net profit of $\$ 20$ million. Raju's also had a 35\% share in Maytas Properties, another real-estate investment firm. Satyam revenues exceeded \$1 billion in 2006. In April, 2008 Satyam became the first Indian company to publish IFRS audited financials. On December 16, 2008, the Satyam board, including its five independent directors had approved the founder's proposal to buy the stake in Maytas Infrastructure and all of Maytas Properties, which were owned by family members of Satyam's Chairman, Ramalinga Raju, as fully owned subsidiary for $\$ 1.6$ billion. Without shareholder approval, the directors went ahead with the management's decision. The decision of acquisition was, however, reversed twelve hours after investors sold Satyam's stock and threatened action against the management. This was followed by the law-suits filed in the US contesting Maytas deal. The World Bank banned Satyam from conducting business for 8 years due to inappropriate payments to staff and inability to provide information sought on invoices. Four independent directors quit the Satyam board and SEBI ordered promoters to disclose pledged shares to stock exchange.

Investment bank DSP Merrill Lynch, which was appointed by Satyam to look for a partner or buyer for the company, ultimately blew the whistle and terminated its engagement with the company soon after it found financial irregularities [29]. On 7 January 2009, Saytam’s Chairman, Ramalinga Raju, resigned after notifying board members and the Securities and Exchange Board of India (SEBI) that Satyam's accounts had been falsified. Raju confessed that Satyam's balance sheet of September 30, 2008, contained the following irregularies: "He faked figures to the extent of Rs. 5040 crore of non-existent cash and bank balances as against Rs. 5361 crore in the books, accrued interest of Rs. 376 crore (non-existent), understated liability of Rs. 1230 crore on account of funds raised by Raju, and an overstated debtor's position of Rs. 490 crore. He accepted that Satyam had reported revenue of Rs. 2700 crore and an operating margin of Rs. 649 crore, while the actual revenue was Rs. 2112 crore and the margin was Rs. 61 crore”. In other words, Raju: 1) inflated figures for cash and bank balances of US $\$ 1.04$ billion vs. US $\$ 1.1$ billion reflected in the books; 2) an accrued interest of US \$77.46 million which was non- 
existent; 3) an understated liability of US \$253.38 million on account of funds was arranged by himself; and 4) an overstated debtors' position of US \$100.94 million vs. US \$546.11 million in the books.

Raju claimed in the same letter that "neither he nor the managing director had benefited financially from the inflated revenues, and none of the board members had any knowledge of the situation in which the company was placed”. The fraud took place to divert company funds into real-estate investment, keep high earnings per share, raise executive compensation, and make huge profits by selling stake at inflated price. The gap in the balance sheet had arisen purely on account of inflated profits over a period that lasted several years starting in April 1999. "What accounted as a marginal gap between actual operating profit and the one reflected in the books of accounts continued to grow over the years. This gap reached unmanageable proportions as company operations grew significantly”, Ragu explained in his letter to the board and shareholders. He went on to explain, "Every attempt to eliminate the gap failed, and the aborted Maytas acquisition deal was the last attempt to fill the fictitious assets with real ones. But the investors thought it was a brazen attempt to siphon cash out of Satyam, in which the Raju family held a small stake, into firms the family held tightly”. Table 1 depicts some parts of the Satyam's fabricated 'Balance Sheet and Income Statement' and shows the "difference" between "actual” and "reported" finances.

Fortunately, the Satyam deal with Matyas was "salvageable". It could have been saved only if "the deal had been allowed to go through, as Satyam would have been able to use Maytas' assets to shore up its own books". Raju, who showed "artificial” cash on his books, had planned to use this "non-existent" cash to acquire the two Maytas companies. As part of their "tunneling” strategy, the Satyam promoters had substantially reduced their holdings in company from 25.6\% in March 2001 to 8.74\% in March 2008. Furthermore, as the promoters held a very small percentage of equity (mere $2.18 \%$ ) on December 2008, as shown in Table 2, the concern was that poor performance would result in a takeover bid, thereby exposing the gap. It was like "riding a tiger, not knowing how to get off without being eaten”. The aborted Maytas acquisition deal was the final, desperate effort to cover up the accounting fraud by bringing some real assets into the business. When that failed, Raju confessed the fraud. Given the stake the Rajus held in Matyas, pursuing the deal would not have been terribly difficult from the perspective of the Raju family. Unlike Enron, which sank due to agency problem, Satyam was brought to its knee due to tunneling. The company with a huge cash pile, with promoters still controlling it with a small per cent of shares (less than $3 \%$ ), and trying to ab-
Table 1. Fabricated balance sheet and income statement of Satyam: as of September 30, 2008.

\begin{tabular}{cccc}
\hline Items Rs. in crore & Actual & Reported & Difference \\
\hline $\begin{array}{c}\text { Cash and Bank } \\
\text { Balances }\end{array}$ & 321 & 5361 & 5040 \\
$\begin{array}{c}\text { Accrued Interest on } \\
\text { Bank Fixed Deposits }\end{array}$ & Nil & 376.5 & 376 \\
Understated Liability & 1230 & None & 1230 \\
Overstated Debtors & 2161 & 2651 & 490 \\
Total & Nil & Nil & 7136 \\
Revenues (Q2 FY 2009) & 2112 & 2700 & 588 \\
Operating Profits & 61 & 649 & 588 \\
\hline
\end{tabular}

Table 2. Promoter's shareholding pattern in Satyam from 2001 to 2008.

\begin{tabular}{cc}
\hline As on & Promoter's holding in \% \\
\hline March 2001 & 25.6 \\
2002 & 22.26 \\
2003 & 20.74 \\
2004 & 17.35 \\
2005 & 15.67 \\
2006 & 14.02 \\
2007 & 8.79 \\
2008 & 8.74 \\
Dec. 2008 & 2.18 \\
\hline
\end{tabular}

sorb a real-estate company in which they have a majority stake is a deadly combination pointing prima facie to tunneling [30]. The reason why Ramalinga Raju claims that he did it was because every year he was fudging revenue figures and since expenditure figures could not be fudged so easily, the gap between "actual" profit and "book" profit got widened every year. In order to close this gap, he had to buy Maytas Infrastructure and Maytas Properties. In this way, "fictitious" profits could be absorbed through a "self-dealing" process. The auditors, bankers, and SEBI, the market watchdog, were all blamed for their role in the accounting fraud.

\subsection{The Auditors Role and Factors Contributing to Fraud}

Global auditing firm, PricewaterhouseCoopers (PwC), audited Satyam's books from June 2000 until the discovery of the fraud in 2009. Several commentators criticized PwC harshly for failing to detect the fraud. Indeed, PwC signed Satyam's financial statements and was responsible for the numbers under the Indian law. One particularly 
troubling item concerned the $\$ 1.04$ billion that Satyam claimed to have on its balance sheet in "non-interestbearing” deposits. According to accounting professionals, "any reasonable company would have either invested the money into an interest-bearing account, or returned the excess cash to the shareholders. The large amount of cash thus should have been a 'red-flag' for the auditors that further verification and testing was necessary. Furthermore, it appears that the auditors did not independently verify with the banks in which Satyam claimed to have deposits”.

Additionally, the Satyam fraud went on for a number of years and involved both the manipulation of balance sheets and income statements. Whenever Satyam needed more income to meet analyst estimates, it simply created "fictitious" sources and it did so numerous times, without the auditors ever discovering the fraud. Suspiciously, Satyam also paid PwC twice what other firms would charge for the audit, which raises questions about whether $\mathrm{PwC}$ was complicit in the fraud. Furthermore, $\mathrm{PwC}$ audited the company for nearly 9 years and did not uncover the fraud, whereas Merrill Lynch discovered the fraud as part of its due diligence in merely 10 days. Missing these "red-flags" implied either that the auditors were grossly inept or in collusion with the company in committing the fraud. PWC initially asserted that it performed all of the company's audits in accordance with applicable auditing standards.

Numerous factored contributed to the Satyam fraud. The independent board members of Satyam, the institutional investor community, the SEBI, retail investors, and the external auditor-none of them, including professional investors with detailed information and models available to them, detected the malfeasance. The following is a list of factors that contributed to the fraud: greed, ambitious corporate growth, deceptive reporting practices-lack of transparency, excessive interest in maintaining stock prices, executive incentives, stock market expectations, nature of accounting rules, ESOPs issued to those who prepared fake bills, high risk deals that went sour, audit failures (internal and external), aggressiveness of investment and commercial banks, rating agencies and investors, weak independent directors and audit committee, and whistle-blower policy not being effective.

\subsection{Aftermath of Satyam Scandal}

Immediately following the news of the fraud, Merrill Lynch terminated its engagement with Satyam, Credit Suisse suspended its coverage of Satyam, and PricewaterhouseCoopers (PwC) came under intense scrutiny and its license to operate was revoked. Coveted awards won by Satyam and its executive management were stripped from the company. Satyam's shares fell to 11.50 rupees on January 10, 2009, their lowest level since March 1998, compared to a high of 544 rupees in 2008. In the New York Stock Exchange, Satyam shares peaked in 2008 at US \$ 29.10; by March 2009 they were trading around US $\$ 1.80$. Thus, investors lost $\$ 2.82$ billion in Satyam. Unfortunately, Satyam significantly inflated its earnings and assets for years and rolling down Indian stock markets and throwing the industry into turmoil [31]. Criminal charges were brought against Mr. Raju, including: criminal conspiracy, breach of trust, and forgery. After the Satyam fiasco and the role played by PwC, investors became wary of those companies who are clients of PwC, which resulted in fall in share prices of around 100 companies varying between $5 \%-15 \%$. The news of the scandal (quickly compared with the collapse of Enron) sent jitters through the Indian stock market, and the benchmark Sensex index fell more than 5\%. Shares in Satyam fell more than $70 \%$. The chart titled as "Fall from grace”, shown in Exhibit 1 depicts the Satyam's stock decline between December 2008 and January 2009.

Immediately after Raju's revelation about the accounting fraud, "new" board members were appointed and they started working towards a solution that would prevent the total collapse of the firm. Indian officials acted quickly to try to save Satyam from the same fate that met Enron and WorldCom, when they experienced large accounting scandals. The Indian government "immediately started an investigation, while at the same time limiting its direct participation, with Satyam because it did not want to appear like it was responsible for the

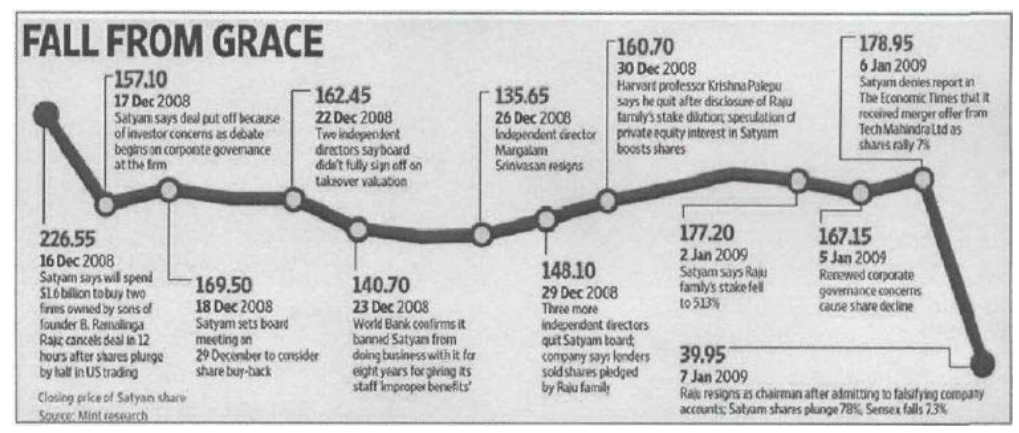

Exhibit 1. Stock Charting of Satyam from December 2008 to January 2009. 
fraud, or attempting to cover up the fraud". The government appointed a "new" board of directors for Satyam to try to save the company. The Board's goal was "to sell the company within 100 days". To devise a plan of sale, the board met with bankers, accountants, lawyers, and government officials immediately. It worked diligently to bring stability and confidence back to the company to ensure the sale of the company within the 100-day time frame. To accomplish the sale, the board hired Goldman Sachs and Avendus Capital and charged them with selling the company in the shortest time possible.

By mid-March, several major players in the IT field had gained enough confidence in Satyam's operations to participate in an auction process for Satyam. The Securities and Exchange Board of India (SEBI) appointed a retired Supreme Court Justice, Justice Bharucha, to oversee the process and instill confidence in the transaction. Several companies bid on Satyam on April 13, 2009. The winning bidder, Tech Mahindra, bought Satyam for $\$ 1.13$ per share-less than a third of its stock market value before Mr. Raju revealed the fraud-and salvaged its operations [32]. Both Tech Mahindra and the SEBI are now fully aware of the full extent of the fraud and India will not pursue further investigations. The stock has again stabilized from its fall on November 26, 2009 and, as part of Tech Mahindra, Saytam is once again on its way toward a bright future.

\subsection{Investigation: Criminal and Civil Charges}

The investigation that followed the revelation of the fraud has led to charges against several different groups of people involved with Satyam. Indian authorities arrested Mr. Raju, Mr. Raju's brother, B. Ramu Raju, its former managing director, Srinivas Vdlamani, the company's head of internal audit, and its CFO on criminal charges of fraud. Indian authorities also arrested and charged several of the company's auditors ( $\mathrm{PwC}$ ) with fraud. The Institute of Chartered Accountants of India [33] ruled that "the $\mathrm{CFO}$ and the auditor were guilty of professional misconduct". The CBI is also in the course of investigating the CEO's overseas assets. There were also several civil charges filed in the US against Satyam by the holders of its ADRs. The investigation also implicated several Indian politicians. Both civil and criminal litigation cases continue in India and civil litigation continues in the United States. Some of the main victims were: employees, clients, shareholders, bankers and Indian government.

In the aftermath of Satyam, India's markets recovered and Satyam now lives on. India's stock market is currently trading near record highs, as it appears that a global economic recovery is taking place. Civil litigation and criminal charges continue against Satyam. Tech Mahindra purchased 51\% of Satyam on April 16, 2009, successfully saving the firm from a complete collapse. With the right changes, India can minimize the rate and size of accounting fraud in the Indian capital markets.

\subsection{Corporate Governance Issues at Satyam}

On a quarterly basis, Satyam earnings grew. Mr. Raju admitted that the fraud which he committed amounted to nearly \$276 million. In the process, Satyam grossly violated all rules of corporate governance [34]. The Satyam scam had been the example for following "poor" CG practices. It had failed to show good relation with the shareholders and employees. CG issue at Satyam arose because of non-fulfillment of obligation of the company towards the various stakeholders. Of specific interest are the following: distinguishing the roles of board and management; separation of the roles of the CEO and chairman; appointment to the board; directors and executive compensation; protection of shareholders rights and their executives.

\subsection{Lessons Learned from Satyam Scam}

The 2009 Satyam scandal in India highlighted the nefarious potential of an improperly governed corporate leader. As the fallout continues, and the effects were felt throughout the global economy, the prevailing hope is that some good can come from the scandal in terms of lessons learned [35]. Here are some lessons learned from the Satyam Scandal:

- Investigate All Inaccuracies: The fraud scheme at Satyam started very small, eventually growing into $\$ 276$ million white-elephant in the room. Indeed, a lot of fraud schemes initially start out small, with the perpetrator thinking that small changes here and there would not make a big difference, and is less likely to be detected. This sends a message to a lot of companies: if your accounts are not balancing, or if something seems inaccurate (even just a tiny bit), it is worth investigating. Dividing responsibilities across a team of people makes it easier to detect irregularities or misappropriated funds.

- Ruined Reputations: Fraud does not just look bad on a company; it looks bad on the whole industry and a country. "India's biggest corporate scandal in memory threatens future foreign investment flows into Asia's third largest economy and casts a cloud over growth in its once-booming outsourcing sector. The news sent Indian equity markets into a tail-spin, with Bombay's main benchmark index tumbling $7.3 \%$ and the Indian rupee fell". Now, because of the Satyam scandal, Indian rivals will come under greater scrutiny by the regulators, investors and customers.

- Corporate Governance Needs to Be Stronger: The Satyam case is just another example supporting the 
need for stronger CG. All public-companies must be careful when selecting executives and top-level managers. These are the people who set the tone for the company: if there is corruption at the top, it is bound to trickle-down. Also, separate the role of CEO and Chairman of the Board. Splitting up the roles, thus, helps avoid situations like the one at Satyam.

The Satyam Computer Services' scandal brought to light the importance of ethics and its relevance to corporate culture. The fraud committed by the founders of Satyam is a testament to the fact that "the science of conduct" is swayed in large by human greed, ambition, and hunger for power, money, fame and glory.

\section{Conclusions}

Recent corporate frauds and the outcry for transparency and honesty in reporting have given rise to two outcomes. First, forensic accounting skills have become very crucial in untangling the complicated accounting maneuvers that have obfuscated financial statements. Second, public demand for change and subsequent regulatory action has transformed CG scenario across the globe. In fact, both these trends have the common goal of addressing the investors' concerns about the transparent financial reporting system. The failure of the corporate communication structure, therefore, has made the financial community realize that "there is a great need for skilled professionals that can identify, expose, and prevent structural weaknesses in three key areas: poor corporate governance, flawed internal controls, and fraudulent financial statements [36]. In addition, the CG framework needs to be first of all strengthened and then implemented in "letter as well as in right spirit". The increasing rate of white-collar crimes, without doubt, demands stiff penalties and punishments.

Perhaps, no financial fraud had a greater impact on accounting and auditing profession than Enron, WorldCom, and recently, India's Enron: "Satyam". All these frauds have led to the passage of the Sarbanes-Oxley Act in July 2002, and a new federal agency and financial standard-setting body, the Public Companies Accounting Oversight Board (PCAOB). It also was the impetus for the American Institute of Certified Public Accountants' (AICPA) adoption of SAS No. 99, "Consideration of Fraud in a Financial Statement Audit" [37]. But it may be that the greatest impact of Enron and WorldCom was in the significant increased focus and awareness related to fraud. It establishes external auditors' responsibility to plan and perform audits to provide a reasonable assurance that the audited financial statements are free of material frauds.

As part of this research study, one of the key objectives was "to examine and analyze in-depth the Satyam Com- puters Limited's accounting scandal by portraying the sequence of events, the aftermath of events, the key parties involved, major reforms undertaken in India, and learn some lessons from it”. Unlike Enron, which sank due to "agency" problem, Satyam was brought to its knee due to "tunneling". The Satyam scandal highlights the importance of securities laws and CG in emerging markets. There is a broad consensus that emerging market countries must strive to create a regulatory environment in their securities markets that fosters effective CG. India has managed its transition into a global economy well, and although it suffers from CG issues, it is not alone as both developed countries and emerging countries experience accounting and CG scandals. The Satyam scandal brought to light, once again, the importance of ethics and its relevance to corporate culture. The fraud committed by the founders of Satyam is a testament to the fact that "the science of conduct is swayed in large by human greed, ambition, and hunger for power, money, fame and glory". All kind of scandals/frauds have proven that there is a need for good conduct based on strong ethics. The Indian government, in Satyam case, took very quick actions to protect the interest of the investors, safeguard the credibility of India, and the nation's image across the world. Moreover, Satyam fraud has forced the government to re-write CG rules and tightened the norms for auditors and accountants. The Indian affiliate of $\mathrm{PwC}$ "routinely failed to follow the most basic audit procedures. The SEC and the PCAOB fined the affiliate, PwC India, \$7.5 million which was described as the largest American penalty ever against a foreign accounting firm" [38]. According to President, ICAI (January 25, 2011), "The Satyam scam was not an accounting or auditing failure, but one of CG. This apex body had found the two PWC auditors prima-facie guilty of professional misconduct". The CBI, which investigated the Satyam fraud case, also charged the two auditors with "complicity in the commission of the fraud by consciously overlooking the accounting irregularities".

The culture at Satyam, especially dominated by the board, symbolized an unethical culture. On one hand, his rise to stardom in the corporate world, coupled with immense pressure to impress investors, made Mr. Raju a "compelled leader to deliver outstanding results". On the contrary, Mr. Raju had to suppress his own morals and values in favor of the greater good of the company. The board connived with his actions and stood as a blind spectator; the lure of big compensation to members further encouraged such behavior. But, in the end, truth is sought and those violating the legal, ethical, and societal norms are taken to task as per process of law. The public confession of fraud by Mr. Ramalinga Raju speaks of integrity still left in him as an individual. His acceptance of guilt and blame for the whole fiasco shows a bright 
spot of an otherwise "tampered" character. After quitting as Satyam's Chairman, Raju said, "I am now prepared to subject myself to the laws of land and face consequences thereof". Mr. Raju had many ethical dilemmas to face, but his persistent immoral reasoning brought his own demise. The fraud finally had to end and the implications were having far reaching consequences. Thus, Satyam scam was not an accounting or auditing failure, but one of CG. Undoubtedly, the government of India took prompt actions to protect the interest of the investors and safeguard the credibility of India and the nation's image across the world. In addition, the CG framework needs to be strengthened, implemented both in "letter as well as in right spirit”, and enforced vigorously to curb white-collar crimes.

\section{REFERENCES}

[1] ACFE, "Report to the Nation on Occupational Fraud and Abuse," The Association of Certified Fraud Examiners, 2010. www.acfe.com

[2] COSO, “Fraudulent Financial Reporting: 1987-2007," Committee of Sponsoring Organizations of the Treadway Commission, 2010. http://www.coso.org

[3] KPMG Fraud Survey 2009, 2003, 1998, 1994. www.kpmginstiutes.com

[4] Deloitte Forensic Center, "Fraud, Bribery and Corruption Practices Survey,” 2011. http://www.deloitte.com.

[5] National Fraud Authority, “Annual Fraud Indicator,” 2012. www.homeoffice.gov.uk

[6] W. K. Black, "Epidemics of Control Fraud Lead to Recurrent, Intensifying Bubbles and Crises," University of Missouri, Kansas City, 2010.

[7] Ernst \& Young, "Detecting Financial Statement Fraud: What Every Manager Needs to Know,” E \& Y LLP, London, 2009, pp. 1-8. www.ey.com

[8] A. R. Reuber and E. Fischer, “Organizations Behaving Badly: When Are Discreditable Actions Likely to Damage Organizational Reputation?” Journal of Business Ethics, Vol. 93, No. 1, 2009, pp. 39-50. doi:10.1007/s10551-009-0180-3

[9] D. L. Crumbley, L. E. Heitger and G. S. Smith, "Forensic and Investigative Accounting Chicago: $\mathrm{CCH}$ Incorporated," 2003.

[10] C. E. Crutchley, M. R. H. Jensen and Marshall, "Climate for Scandal: Corporate Environments that Contribute to Accounting Fraud,” The Financial Review, Vol. 42, No. 1, 2007, pp. 53-73.

[11] R. Jeffords, "How Useful Are the Treadway Risk Factors?” Internal Auditor, Vol. 49, No. 3, 1999, pp. 12-30.

[12] E. R. Smith, "A Positive Approach to Dealing with Embezzlement," The White Paper, August/September 1995 pp. 17-18.

[13] D. E. Ziegenfuss, "State and Local Government Fraud Survey for 1995,” Managerial Auditing Journal, Vol. 11,
No. 9, 1996, pp. 50-55. doi:10.1108/02686909610150395

[14] S. Haugen and J. R. Selin, "Identifying and Controlling Computer Crime and Employee Fraud,” Industrial Management \& Data Systems, Vol. 99, No. 8, 1999, pp. 340344. doi:10.1108/02635579910262544

[15] Sharma, S. and Brahma, “A Role of Insider in Banking Fraud,” 2000. http://manuputra.com

[16] Harris and William, "The Two Faces of the Transgender Fraudster Who Made Thousands of Pounds in Scams Posing as Both Sexes,” 2004.

[17] J. L. Beirstaker, R. G. Brody and C. Pacini, “Accountants' Perceptions Regarding Fraud Detection and Prevention Methods,” Managerial Auditing Journal, Vol. 21. No. 5, 2006, pp. 520-535. doi:10.1108/02686900610667283

[18] R. Willison, "Understanding the Offender/Environment Dynamic for Computer Crimes," Information Technology \& People, Vol. 19, No. 2, 2006, pp. 170-186. doi:10.1108/09593840610673810

[19] F. Choo and K. Tan, "An American Dream Theory of Corporate Executive Fraud,” Accounting Forum, Vol. 31, No. 2, 2007, pp. 203-215. doi:10.1016/j.accfor.2006.12.004

[20] Schrand and Zechman, "Executive Overconfidence and the Slippery Road to Fraud,” 2007. http://faculty.chicagobooth.edu

[21] M. L. Bhasin, "Corporate Governance and Role of the Forensic Accountant," The Chartered Secretary Journal, Vol. 38, No. 10, 2008, pp. 1361-1368.

[22] S. Chen, "The Role of Ethical Leadership Versus Institutional Constraints: A Simulation Study of Financial Misreporting by CEOs,” Journal of Business Ethics, Vol. 93, No. 1, 2010, pp. 33-52. doi:10.1007/s10551-010-0625-8

[23] M. Cecchini, H. Aytug, G. J. Koehler and P. Pathak, "Detecting Management Fraud in Public Companies," Management Science, Vol. 56, No. 7, 2010, pp. 11461160. doi:10.1287/mnsc.1100.1174

[24] E. Basilico, H. Grove and L. Patelli, “Asia’s Enron: Satyam,” Journal of Forensic \& Investigative Accounting, Vol. 4. No. 2, 2012, pp. 142-160.

[25] T. Ahmad, T. Malawat, Y. Kochar and A. Roy, "Satyam Scam in the Contemporary Corporate World: A Case Study in Indian Perspective,” IUP Journal, 2010, pp. 1-48. www.ssrn.com/abstract $=1460022$

[26] S. Agrawal and R. Sharma, "Beat This: Satyam Won Awards for Corporate Governance, Internal Audit," VCCircle, 2009. www.vccircle.com/news

[27] S. Ramachadran, "Raju Brings Down Satyam, Shakes India,” Asia Times Online Ltd., 2009. www.a.times.com

[28] M. Damodaran, "Listed Firms to Get New Conduct Code,” Financial Chronicle, 2009. http://wrd.mydigitalfc.com.

[29] R. M. Bowen, A. C. Call and S. Rajgopal, "WhistleBlowing: Target Firm Characteristics and Economic Consequences,” The Accounting Review, Vol. 85, No. 4, 2010, pp. 1239-1271. doi:10.2308/accr.2010.85.4.1239

[30] S. Shirur, "Tunneling vs. Agency Effect: A Case Study of Enron and Satyam,” Vikalpa, Vol. 36, No. 3, 2011, pp. 
9-20.

[31] H. Timmons and B. Wassener, "Satyam Chief Admits Huge Fraud,” New York Times, 8 January 2009. www.nytimes.com

[32] S. S. Dagar, "How Satyam Was Sold the Untold Story: How the IT Services Major Was Rescued against all Odds. Business Today Reconstructs the Events of the 14 Crucial Weeks that Led up to the Sale,” Business Today, 2009, pp. 25-42.

[33] ICAI, "ICIA Finds ex Satyam CFO, Price Waterhouse Auditors Guilty,” Outlook, 2009.

[34] R. Chakrabarti, W. Megginson and P. K. Yadav, "Corporate Governance in India,” Journal of Applied Corporate Finance, Vol. 20, No. 1, 2008, pp. 59-78. doi:10.1111/j.1745-6622.2008.00169.x

[35] B. Behan, "Governance Lessons from India's Satyam,” Business Week, 16 January 2009.

[36] Z. Rezaee and B. L. Kedia, "Role of Corporate Governance Participants in Preventing and Detecting Financial Statement Fraud," Journal of Forensic \& Investigative Accounting, Vol. 4, No. 2, 2012, pp. 176-205.

[37] AICPA, "SAP-99: Consideration of Fraud in a Financial Statement Audit. Auditing Standard Board,” 2002. http://www.aicpa.org

[38] F. Norris, “Indian Accounting Firm Is Fined \$7.5 Million over Fraud at Satyam," The New York Times, 5 April 2011. 


\section{Annexure: Satyam's Founder, Chairman and CEO, Mr. Raju's Letter to His Board of Directors}

To The Board of Directors,

Satyam Computer Services Ltd.

From: B. Ramalinga Raju

Chairman, Satyam Computer Services Ltd.

January 7, 2009

Dear Board Members,

It is with deep regret, and tremendous burden that I am carrying on my conscience, that I would like to bring the following facts to your notice:

1) The Balance Sheet carries as of September 30, 2008:

a) Inflated (non-existent) cash and bank balances of Rs. 5040 crore (as against Rs. 5361 crore reflected in the books); b) An accrued interest of Rs. 376 crore which is non-existent; c) An understated liability of Rs. 1230 crore on account of funds arranged by me; and d) An over stated debtors position of Rs. 490 crore (as against Rs. 2651 reflected in the books).

2) For the September quarter (Q2), we reported a revenue of Rs. 2700 crore and an operating margin of Rs. 649 crore ( $24 \%$ of revenues) as against the actual revenues of Rs. 2112 crore and an actual operating margin of Rs. 61 crore (3\% of revenues). This has resulted in artificial cash and bank balances going up by Rs. 588 crore in Q2 alone.

The gap in the Balance Sheet has arisen purely on account of inflated profits over a period of last several years (limited only to Satyam standalone, books of subsidiaries reflecting true performance). What started as a marginal gap between actual operating profit and the one reflected in the books of accounts continued to grow over the years. It has attained unmanageable proportions as the size of company operations grew significantly (annualized revenue run rate of Rs. 11,276 crore in the September quarter, 2008 and official reserves of Rs. 8392 crore). The differential in the real profits and the one reflected in the books was further accentuated by the fact that the company had to carry additional resources and assets to justify higher level of operations - thereby significantly increasing the costs.

Every attempt made to eliminate the gap failed. As the promoters held a small percentage of equity, the concern was that poor performance would result in a take-over, thereby exposing the gap. It was like riding a tiger, not knowing how to get off without being eaten.

The aborted Maytas acquisition deal was the last attempt to fill the fictitious assets with real ones. Maytas' investors were convinced that this is a good divestment opportunity and a strategic fit. Once Satyam's problem was solved, it was hoped that Maytas' payments can be delayed. But that was not to be. What followed in the last several days is common knowledge.

I would like the Board to know:

1) That neither myself, nor the Managing Director (including our spouses) sold any shares in the last eight years-excepting for a small proportion declared and sold for philanthropic purposes.

2) That in the last two years a net amount of Rs. 1230 crore was arranged to Satyam (not reflected in the books of Satyam) to keep the operations going by resorting to pledging all the promoter shares and raising funds from known sources by giving all kinds of assurances (Statement enclosed, only to the members of the board). Significant dividend payments, acquisitions, capital expenditure to provide for growth did not help matters. Every attempt was made to keep the wheel moving and to ensure prompt payment of salaries to the associates. The last straw was the selling of most of the pledged share by the lenders on account of margin triggers.

3) That neither me, nor the Managing Director took even one rupee/dollar from the company and have not benefited in financial terms on account of the inflated results.

4) None of the board members, past or present, had any knowledge of the situation in which the company is placed. Even business leaders and senior executives in the company, such as, Ram Mynampati, Subu D., T. R. Anand, Keshab Panda, Virender Agarwal, A. S. Murthy, Hari T., S. V. Krishnan, Vijay Prasad, Manish Mehta, Murali V., Sriram Papani, Kiran Kavale, Joe Lagioia, Ravindra Penumetsa, Jayaraman and Prabhakar Gupta are unaware of the real situation as against the books of accounts. None of my or Managing Director's immediate or extended family members has any idea about these issues.

Having put these facts before you, I leave it to the wisdom of the board to take the matters forward. However, I am also taking the liberty to recommend the following steps:

1) A Task Force has been formed in the last few days to address the situation arising out of the failed Maytas acquisition attempt. This consists of some of the most accomplished leaders of Satyam: Subu D., T. R. Anand, Keshab Panda and Virender Agarwal, representing business functions, and A. S. Murthy, Hari T. and Murali V. representing support functions. I suggest that Ram Mynampati be made the Chairman of this Task Force to immediately address some of the operational matters on hand. Ram can also act as an interim CEO reporting to the board.

2) Merrill Lynch can be entrusted with the task of quickly exploring some Merger opportunities.

3) You may have a "restatement of accounts" prepared by the auditors in light of the facts that I have placed 
before you. I have promoted and have been associated with Satyam for well over twenty years now. I have seen it grow from few people to 53,000 people, with 185 Fortune 500 companies as customers and operations in 66 countries. Satyam has established an excellent leadership and competency base at all levels. I sincerely apologize to all Satyamites and stakeholders, who have made Satyam a special organization, for the current situation. I am confident they will stand by the company in this hour of crisis. In light of the above, I fervently appeal to the board to hold together to take some important steps. Mr. T. R. Prasad is well placed to mobilize support from the government at this crucial time. With the hope that members of the Task Force and the financial advisor,
Merrill Lynch (now Bank of America) will stand by the company at this crucial hour, I am marking copies of this statement to them as well.

Under the circumstances, I am tendering my resignation as the chairman of Satyam and shall continue in this position only till such time the current board is expanded. My continuance is just to ensure enhancement of the board over the next several days or as early as possible.

I am now prepared to subject myself to the laws of the land and face consequences thereof.

Signature

(B. Ramalinga Raju)

(Source: Bombay Stock Exchange; Security and Exchange Board of India, available at www.sebi.gov.in) 